\title{
Portrayal of Women in Major World Religions
}

\section{- Eak Prasad Duwadi}

For Hindus mother is treated as Goddess. There should be no error in the duties towards the gods and females. Women must be honoured to ensure the gods are happy, to maintain a family unit and for happiness (Manu Smriti, Chapter 3). Let your mother be a goddess unto you. Let your father be a god unto you. Let your teacher be a god unto you. Let your guest be a god unto you. The works that are not blameworthy are to be resorted to, but not the others (Taittiriya Upanishad).

God is described as both Male and Female which implies both are equal. Thou alone art the woman, the man; again. Thou art the boy and the girl. Thou art the ordainer, the King Varuna, the Year, Aryama, the all (Ekakshara Upanishad). Both men and women can attain salvation (Bhasma-Jabala Upanishad ):

Rudra is man. Uma is woman. Prostrations to Him and Her. Rudra is Brahma. Uma is Sarasvati. Prostrations to Him and Her. Rudra is Vishnu. Uma is Lakshmi. Prostrations to Him and Her. Rudra is the Sun. Uma is shadow. Prostrations to Him and Her. Rudra is the Moon. Uma is star. Prostrations to Him and Her. Rudra is day. Uma is night. Prostrations to Him and Her. Rudra is Yajna. Uma is Vedi. Prostrations to Him and Her. Rudra is Agni, Uma is Svaha. Prostrations to Him and Her. Rudra is Veda. Uma is Sastra. (Rudra-Hridaya Upanishad)

In Hinduism Shakti (all power) is female and is the divine feminine power found in everything. The Vedic pantheon of Gods includes a substantial number of female goddesses. God is again described as having two different facets, both of which are worthy of veneration and praise. The Vamadevya Saman is woven in a couple. He who thus knows this Vamadevya Saman as woven in a couple becomes one of the couple and procreates. He reaches the full length of life, lives gloriously, and becomes great with offspring and cattle, and 
great also with fame. His holy vow is that he should not despise any woman (The Chandogya Upanishad).

Having sex with a low caste women is considered a sin (KaliSantarana Upanishad ) and marriage to a low caste woman is a sin, associates of a remarried woman are bad and a menstruating women should be avoided (Manu Smriti, Chapter 3 ). Menstruating women considered bad, sex with a women is considered impure and women should not be allowed independence (Manu Smriti, Chapter 4). Unequal laws for men and women including the death penalty, body mutilation and no property allowed (Manu Smriti, Chapter 8). Women should be kept in dependence (Manu Smriti, Chapter 9). Women are described as evil agents of cupid designed to destroy men:

Having (attractive) hair and putting on collyrium, women, difficult to touch but pleasing to the eyes are (verily) the flames of the fire of sin and they burn men as though they were straw. Women pleasing and cruel, are the fuel for the hell-fires, that inflame even at a distance and though juicy (loveable) are devoid of moisture (flavor). Silly women are the nets spread by the hunter called Cupid to entangle the bodies of men in the form of birds. Woman is the bait stuck in the fish-hook at the string of evil propensity to catch men in the form of fish that are in the pond of worldly life and that are active in the mud of the mind. (Yajnavalkya Upanishad)

Varaha Upanishad encourages the practice of looking at women as dead beings to avoid attraction and Maha Upanishada is one step ahead to chide women:

Women are the traps to catch the birds - men, spread by the hunter, Manmatha, the lump of bait, the string of wickedness to men who are the fish in the pond of birth (life) and moving in the mud of mind. I will have none of this woman who is the basket of all defects - gems - the chain of misery. Only he with a woman has desire for enjoyment; where is enjoyment for one who has no woman? Giving up women means giving up the world; by this one shall be happy. (Maha Upanishad) 
Women are regarded as sin traps that will bring misery to men. Speaking with a low caste woman is regarded as a hindrance to heaven. On seeing a young beautiful woman (he) becomes inflamed with passion, and drinking liquor he becomes intoxicated. Therefore he shall avoid from afar a woman who is poison to the eye (Narada-Parivrajaka Upanishad). Women are to be regarded as poison.

Women were encouraged to practice Sati (burning of the widow on the funeral pyre). Sati (burning of widow on funeral pyre) sanctioned since the time of Krishna as something honourable. Here are three excerpts of sati sysem:

Many years ago there used to be a king known as Shatadhanu. His wife Shaivya was a religious woman. Together, they used to pray to Vishnu, on the banks of the river Bhagirathi. They were not interested in other things. One day a fraudulent teacher came to them. Shatadhanu spoke to this person, but Shaivya did not. Some years later, Shatadhanu died and Shaivya also died with him on the funeral pyre.

King Janaka was performing an ashvamedha sacrifice. The peacock had a bath at the time of the sacrifice. When Shaivya reminded the peacock of its earlier life, it died. It was now born as the son of Janaka and Shaivya agreed to marry him. After Janaka died, his son became the ruler of the kingdom of Videha. In this life Shatadhanu performed many sacrifices and gave much alms. He had several sons and ruled the kingdom and the earth well. When he died, Shaivya again died on the funeral pyre with him. Husband and wife went to heaven.

Arjuna found the dead bodies of Krishna, Balarama and other important Yadavas and performed their shraddha ceremonies. Krishna's eight major wives died on Krishna's funeral pyre. Revati did the same on Balarama's . Urgasena, Rohini, Devaki and Vasudeva also entered a fire. The others left Dvaraka with Arjuna. As soon as Krishna died, the Parijata tree and the assembly hall named Sudharma returned to heaven. The Kali era began. And the city of Dvaraka was swallowed up by the sea, with the exception of Krishna's own dwelling. (Vishnu Purana) 
In this way, women were encouraged to burn themselves in Hindu cultures till a few century back. However, there is not a single record of the male (king or soldier) who went to sati with their wives. Most intriguing fact is that there were 407 Sages associated with the revelation of Rig Veda, of which 17 were women, but even they have deduced that women are undisciplined with little intellect (Rig Veda).

In Jainism qualities of a mother are regarded highly, rules for Yatis (salvation) are the same for men and women, and some women are regarded as goddesses on Earth:

He observes the most difficult but pious virtue of celibacy, who does not entertain evil thoughts even after looking at all the organs of woman (112). Just as a jar made of lac (sealing wax) when placed near fire soon gets melted and perished. Similarly a monk who moves in the company of women looses his character (113). One, who overcomes desires for association with women, can overcome other temptations of his life as easily as a person, who has crossed an ocean, can easily cross the river Ganges (114). Just as women become censurable by men observing celibacy, similarly men become censurable by women observing celibacy (115). But there are women endowed with stern character, renowned far and wide, who are goddesses on this earth and are even adorned by gods (116). The sexual fire fed by the trees of desires can burn the forest of the three worlds; one is blessed whose grass of youthful life remains unburned by this fire (117). (Saman Suttam, 9. Dharmasutra)

There are other contradictory assumptions that the company of women are bad. They encourage men to avoid females. Women should be avoided by males if they want to obtain salvation to avoid sexual thoughts in the mind (Prashmartiprakranam, Ath Aacharadhikar: 8). Women are not considered capable of salvation due to their menstrual cycle, their inherent nature and as because they are advised to wear clothing (which will hinder any opportunity of salvation). Women are enjoined to wear a minimum one piece of clothing with which they may not obtain emancipation (Ashta Pahuda, Acharya Kund Kund). They are 
given the same status as animals and immoral people and teaching and educating women is considered to be a road to hell.

Thus, there are objectionable assumptions of women that a menstruating woman is considered bad, women are given the same status as animals and immoral people, teaching and educating women is considered bad for a male and women should generally be avoided if a male is looking for emancipation.

In Buddhism salvation is open for men and women (Amitabha Sutra). Both men and women are given the opportunity to listen to religious discourse:

A disciple of the Buddha should not be selective and show preference in conferring the Bodhisattva precepts. Each and every person can receive the precepts -- kings, princes, high officials, Bhiksus, Bhiksunis, laymen, laywomen, libertines, prostitutes, the gods in the eighteen Brahma Heavens or the six Desire Heavens, asexual persons, bisexual persons, eunuchs, slaves, or demons and ghosts of all types. Buddhist disciples should be instructed to wear robes and sleep on cloth of a neutral color, formed by blending blue, yellow, red, black and purple dyes all together. (Brahma Net Sutra)

Buddhist Nuns had achieved Nirvana and their incarnation as a woman was to help inferior living beings. There were also innumerable Bhikshunis headed by Maha-Prajapati. All of them had already accomplished the meritorious virtues of great and wise men, in order to soothe the inferior living beings; they appeared as women (Tathagata's Unimaginable State Sutra). However, disparity even looms over in Buddhism as the Buddha allows women to join the priesthood but only if they follow 8 special rules. Those rules involve a subordination of Bhikkhunis to Bhikkhus (Guide to TipiTaka - Pali Buddhist Canonical Scriptures). 
There are other derogatory against women-- a woman is regarded as lower than a man (The Sutra of 42 Sections Spoken by the Buddha). A monk should avoid talk with women to avoid inappropriate thoughts in the mind (SadharmaPundarika).Women are compared to evil destinies and suffering (Sutra of the Merit and Virtue of the Past Vows of the Medicine Master). The intellect of a mother is regarded as having little wisdom because they spend large amounts of time looking after children. However this same Sutra talks about the 10 types of Kindness that a mother gives her baby (Filial Piety Sutra).

In Taoism men and women can both realise truth and women are given the responsibility of maintaining the family unit (I Ching). Female energy is used to describe Tao. Ying and Yang complement each other- it worships femininity. We cannot have one without the other. So in this sense both the men and women are given high importance as they are respectively the opposites of one another. Nevertheless gender disparity does not end here. Not unlike in other religions women are considered the weaker sex and women should follow men:

A woman should follow a man her whole life long, but a man should at all times hold to what is his duty at the given moment. Should he persistently seek to conform to the woman, it would be a mistake for him. Accordingly it is altogether right for a woman to hold conservatively to tradition, but a man must always be flexible and adaptable and allow himself to be guided solely by what his duty requires of him at the moment.

A king is the symbol of a fatherly man who is richly endowed in mind. He does nothing to make himself feared; on the contrary, the whole family can trust him, because love governs their intercourse. His character of itself exercises the right influence. Nine at the top means: His work commands respect.' In the end good fortune comes. In the last analysis, order within the family depends on the character of the master of the house. If he cultivates his personality so that it works impressively through the force of inner truth, all goes well 
with the family. In a ruling position one must of his own accord assume responsibility.

A father is able to give his daughter in marriage when he deems suitable. (Tao Te Ching)

In Islam both believing men and women will be provided forgiveness and a vast reward (Quran). A woman who wants divorce must be treated with respect. The dowry of women is safeguarded and they must be treated with kindness. Women have a legal share to inheritance. Nonetheless, polygamy is allowed. Menstruation is regarded as an illness during which time women should be left alone. Death is the punishment for an unfaithful woman. Testimony of 2 women is equal to the testimony of 1 man. Women who are captured in war can be sexually violated even if they are married. Men are in charge of women:

Men are in charge of women, because Allah hath made the one of them to excel the other, and because they spend of their property (for the support of women). So good women are the obedient, guarding in secret that which Allah hath guarded. As for those from whom ye fear rebellion, admonish them and banish them to beds apart, and scourge them. Then if they obey you, seek not a way against them. Lo! Allah is ever High, Exalted, Great. (Quran)

Women assumed to be bad as majority in hell are women (Sahih Bukhari, Volume 1, Book 2, Number 28). Women are regarded as deficient in intelligence and religion (Sahih Bukhari Volume 1, Book 6, Number 301). Women are likened to dogs and donkeys (Sahih Bukhari, Vol. 1 Book 9, Number 490). Men are also allowed to beat / scourge their women (Quran).

Men have a degree over women. Women are regarded as a tilth and compared with dogs and donkeys. Women regarded deficient in intelligence and religion. Women are assumed bad as majority in hell are women. Death is the price for an unfaithful woman. Polygamy is allowed for a Muslim man.

In Christianity the grace of a good woman is above Gold (Deuterocanonical Apocrypha, 7:18 - 7:21). There are lots of 
examples of famous Christian women through history and today. There are a number of Modern Christian groups who follow equality between men and women. The qualities of a good woman are held in high esteem. There is equal treatment for an evil man or woman (Bible, Deuteronomy 17:1-7).

In spite of these positive aspects, nonetheless, there are many unequal treatments. Woman is regarded as wicked:

The fear of the Lord is the beginning of his love and faith is the beginning of cleaving unto him. [Give me] any plague, but the plague of the heart: and any wickedness, but the wickedness of a woman: And any affliction, but the affliction from them that hate me: and any revenge, but the revenge of enemies. There is no head above the head of a serpent; and there is no wrath above the wrath of an enemy. I had rather dwell with a lion and a dragon, than to keep house with a wicked woman. The wickedness of a woman changed her face, and darkened her countenance like sackcloth. Her husband shall sit among his neighbors; and when he heard it shall sigh bitterly. All wickedness is but little to the wickedness of a woman: let the portion of a sinner fall upon her. As the climbing up a sandy way is to the feet of the aged, so is a wife full of words to a quiet man. (Deuterocanonical Apocrypha, 25:12 - 25:20)

Husband to rule over wife (Bible, Genesis 3:16-16). Menstruating woman is considered unclean. Menstruating woman not allowed going to a sacred place. Anything a menstruating woman touches is unclean (Bible Leviticus 12:15). Woman are also regarded as defective and misbegotten (Summa Theologica,Q92, art. 1, Reply Obj). Women are regarded as the source of sin through which we all die:

The Lord said to Moses, "Say to the Israelites: 'A woman who becomes pregnant and gives birth to a son will be ceremonially unclean for seven days, just as she is unclean during her monthly period. On the eighth day the boy is to be circumcised. Then the woman must wait thirty-three days to be purified from her bleeding. She must not touch anything sacred or go to the sanctuary until the days of her purification 
are over. If she gives birth to a daughter, for two weeks the woman will be unclean, as during her period. Then she must wait sixty-six days to be purified from her bleeding. (Deuterocanonical Apocrypha, 25:20 - 25:26).

The Bible regards a menstruating woman as bad in many ways. The husband and/or male is generally given a higher status than a wife and/or female. The early church fathers did not regard women as good. Genesis and the fall of Adam and Eve do not support gender equality as $\sin$ is regarded as the fault of a woman.

In Sikhism the light of God sits equally within both men and women. The cessation of suffering is available to both men and women. A menstruating is not considered impure. Sikhs give more priority to pure mind than to body wash. They are not called pure, who sit down after merely washing their bodies. Only they are pure, O Nanak, within whose minds the Lord abides [2] (p.472). Only people with God in their mind are considered pure, which is independent of the condition of ones clothing or physical body cycles.

As a woman has her periods, month after month, so does falsehood dwell in the mouth of the false; they suffer forever, again and again. When the clothes are soiled and stained by urine, soap can wash them clean. But when the intellect is stained and polluted by sin, it can only be cleansed by the Love of the Name (p. 4). Both men and women are described as beautiful soul brides of God:

From woman, man is born; within woman, man is conceived; to woman he is engaged and married. Woman becomes his friend; through woman, the future generations come. When his woman dies, he seeks another woman; to woman he is bound. So why call her bad? From her, kings are born. From woman, woman is born; without woman, there would be no one at all. O Nanak, only the True Lord is without a woman. That mouth which praises the Lord continually is blessed and beautiful. O Nanak, those faces shall be radiant in the Court of the True Lord. [2] (p. 473) 
Although comparatively there are many aspects of equality between men and women in Sikhism, there are some belittling. For example a woman is regarded as the one half of man:

Because of the love of woman, circumcision is done; I don't believe in it, O Siblings of Destiny. If God wished me to be a Muslim, it would be cut off by itself. [2] If circumcision makes one a Muslim, then what about a woman? She is the other half of a man's body, and she does not leave him, so he remains a Hindu. [3] Give up your holy books, and remember the Lord, you fool, and stop oppressing others so badly. Kabeer has grasped hold of the Lord's Support, and the Muslims have utterly failed. [4] [8]. (p. 477)

Major World religions provide certain degrees of freedom to women. There are also several commonalities between these religions because each gives importance to mother and take menstruation as bad. However they all fall short of providing complete equality.

Hence because of such stereotyped conjectures in each World religion, our world has been and still is dominated by men in all forms including politically, socially, economically, spiritually and legally. And teaching is not an exception-female teachers were also brought up in the same cultural and religious environment where male chauvinism dominated. There has been only reproduction of male domination in different forms.

\section{References}

United Nations Development Fund for Women (2008).

Pathway to gender equality. Bangkok: United Nations Development Fund for Women.

UNESCO (2006). Gender thematic trust fund report 20052006. Bangkok.

UNESCO (2006). The impacts of women teaches on girls' education: Advocacy brief. Bangkok. 
Williams, T. (1993). Cat on the hot tin roof. In L. A. Jacobus (Ed.), The Bedford introduction to drama (pp. 940-986, $\left(2^{\text {nd }}\right.$ ed.). Boston: Bedford Books.

Wolfreys, J. Robbins R. \& Womack, K. (2002). Key concepts in literary theory. Edinburg: Edinburg University Press.

Wollstonecraft, M. (1992). A vindication of rights of woman. In H. Adams (Ed.), Critical theory since Plato (pp. 394-99).

New York: Harcourt Brace.

Woolf, V. (1992). A room of one's own. In H. Adams (Ed.),

Critical theory since Plato (p. 817). New York: Harcourt Brace.

Women equality (2008). Amitabha Sutra. Retrieved August 1, 2008, from http://www.drba.org/dharma/amitabhasutra.asp

Women equality (2008). Ashta Pahuda, Acharya Kund Kund.

Retrieved August 9, 2008, from

http://www.jainworld.com/scriptures/ashtapahuda2.asp

Women equality (2008). Ashta Pahuda, Acharya Kund Kund.

Retrieved August 7, 2008, from

http://www.jainworld.com/scriptures/ashtapahuda2.asp

Women equality (2008). Bhasma-Jabala Upanishad .

Retrieved August 2, 2008, from

http://www.astrojyoti.com/bhasmajabalaupanishad.htm

Women equality (2008). Bible, Deuteronomy 17:1-7. Retrieved

August 10, http://bible.crosswalk.com/OnlineStudyBible/ bible.cgi

Women equality (2008). Bible, Genesis 3:16-16. Retrieved August 11, http://bible.crosswalk.com/OnlineStudyBible Women equality (2008). Bible Leviticus 12:1-5. Retrieved July 1, http://bible.crosswalk.com/OnlineStudyBible/bible.cgi Women equality (2008). Brahma Net Sutra. Retrieved July 3, 2008, from

http://www.purifymind.com/BrahmaNetSutra.htm

Women equality (2008). Deuterocanonical Apocrypha, 25:2025:26. Retrieved August 10,

http://mobile.ishwar.com/christianity/deuterocanonical_apo crypha/book14

Women equality (2008). Deuterocanonical Apocrypha, 25:12 25:20. Retrieved August 10, 
http://mobile.ishwar.com/christianity/deuterocanonical_apo crypha/book14

Women equality (2008). Deuterocanonical Apocrypha, 7:18-

7:21. Retrieved August 10,

http://mobile.ishwar.com/christianity/deuterocanonical_apo crypha/book14

Women equality (2008). Ekakshara Upanishad (A. G. K.

Warrier, Trans.). Retrieved August 10, 2008, from

http://www.astrojyoti.com/EkaksharaUpanishad.htm

Women equality (2008). Filial Piety Sutra. Retrieved August

10, http://www.ic.sunysb.edu/Clubs/buddhism/

sutras/fmeznbj.html

Women equality (2008). Guide to TipiTaka - Pali Buddhist

Canonical Scriptures. Retrieved August 10, 2008, from

http://www.buddhanet.net/ebooks_s.htm

Women equality (2008). Guru Granth Sahib Ji. Retrieved

August 10, http://www.srigranth.org

Women equality (2008). I Ching. Retrieved August 10,

http://www.akirarabelais.com/i/i.html

Women equality (2008). Kali-Santarana Upanishad (N. Aiyar,

Trans.). Retrieved August 10, 2008, from

http://www.astrojyoti.com/KaliSantaranaUpanishad.htm

Women equality (2008). Maha Upanishad (A. G. K. Warrier,

Trans.). Retrieved August 10, 2008, from

http://www.astrojyoti.com/MahaUpanishad.htm

Women equality (2008). Manu Smriti, Chapter 3. Retrieved

August 10, 2008, from http://www.sacred-

texts.com/hin/manu/manu03.htm

Women equality (2008). Manu Smriti, Chapter 4. Retrieved

August 10, 2008, from http://www.sacred-

texts.com/hin/manu/manu04.htm

Women equality (2008). Manu Smriti, Chapter 8. Retrieved

August 10, 2008, from http://www.sacred-

texts.com/hin/manu/manu08.htm

Women equality (2008). Manu Smriti, Chapter 9. Retrieved August 10, 2008, from http://www.sacredtexts.com/hin/manu/manu09.htm 
Women equality (2008). Narada-Parivrajaka Upanishad (A. A. Ramanathan, Trans.). Retrieved August 10, 2008, from http://www.astrojyoti.com/NaradaParivrajakaUpanishad.ht $\mathrm{m}$

Women equality (2008). Prashmartiprakranam, Ath Aacharadhikar: 8 . Retrieved August 10, 2008, from http://www.jainworld.com/book/prasamarati_prakarana/PP 24.htm

Women equality (2008). Quran. Retrieved August 10, 2008, from http://www.usc.edu/dept/MSA/quran/002.qmt.html

Women equality (2008). Quran. Retrieved August 10, 2008, from http://www.usc.edu/dept/MSA/quran/004.qmt.html

Women equality (2008). Quran. Retrieved August 10, 2008, from http://www.usc.edu/dept/MSA/quran/005.qmt.html Women equality (2008). Quran. Retrieved August 10, 2008, from http://www.usc.edu/dept/MSA/quran/006.qmt.html

Women equality (2008). Quran. Retrieved August 10, http://www.usc.edu/dept/MSA/quran/009.qmt.html

Women equality (2008). Quran. Retrieved August 10, 2008, from http://www.usc.edu/dept/MSA/quran/0016.qmt.html

Women equality (2008). Quran. Retrieved August 10, 2008, from http://www.usc.edu/dept/MSA/quran/033.qmt.html

Women equality (2008). Rig Veda. Retrieved August 10, 2008, from http://www.comparative- religion.com

Women equality (2008). Rudra-Hridaya Upanishad. Retrieved August 10, 2008, from

http://www.astrojyoti.com/RudraHridayaUpanishad.htm

Women equality (2008). Sadharma-Pundarika. Retrieved August 10, 2008, from http://www.sacredtexts.com/bud/lotus/lot13.htm

Women equality (2008). Sahih Bukhari, Volume 1, Book 2, Number 28. Retrieved August 10, http://www.usc.edu/dept/MSA/reference/searchhadith.html Women equality (2008). Sahih Bukhari Volume 1, Book 6, Number 301. Retrieved August 10, http://www.usc.edu/dept/MSA/reference/searchhadith.html 
Women equality (2008). Sahih Bukhari, Volume 1, Book9, Number 490. Retrieved August 10, http://www.usc.edu/dept/MSA/reference/searchhadith.html Women equality (2008). Saman Suttam, 9. Dharmasutra.

Retrieved August 10, 2008, from http://www.jainworld.com/scriptures/samansuttam9.asp Women equality (2008). Summa Theologica, Q92, art. 1, Reply

Obj. Retrieved August 10, 2008, from http://en.wikiquote.org/wiki/Thomas_Aquinas

Women equality (2008). Sutra of the Merit and Virtue of the Past Vows of the Medicine Master. Retrieved July 10, 2008, from http://www.buddhistdoor.com/OldWeb/ resources/sutras/medicine sutra.htm

Women equality (2008). The $\bar{C}$ handogya Upanishad (S. Swahananda, Trans.). Retrieved August 8, 2008, from http://www.astrojyoti.com/chandogyaupanishad.htm Women equality (2008). Taittiriya Upanishad. Retrieved August 10, 2008, from http://www.astrojyoti.com/taittiriyaupanishad.htm

Women equality (2008). Tathagata's Unimaginable State Sutra. Retrieved August 6, 2008, from http://www2.fodian.net/old/English/301.html

Women equality (2008). The Sutra of 42 Sections Spoken by the Buddha (U. C. Chan, Trans.). Retrieved August 10, 2008, from http://www4.bayarea.net/ mtlee/42.txt

Women equality (2008). Tao Te Ching. Retrieved August 5, http://www.sacred-texts.com/tao/taote.htm

Women equality (2008). Varaha Upanishad (K. N. Aiyar,

Trans.). Retrieved August 4, 2008, from

http://www.astrojyoti.com/VarahaUpanishad.htm

Women equality (2008). Vishnu Purana. Retrieved August 3, 2008, from

http://www.dharmakshetra.com/literature/puranas/VISHNU .htm

Women equality (2008). Yajnavalkya Upanishad (A. A. Ramanathan, Trans.). Retrieved August 2, 2008, from http://www.astrojyoti.com/YajnavalkyaUpanishad.htm 
Women equality (2008). Yajur Veda, Kanda 2, Prapathaka V. Retrieved August 1, 2008, from http://www.comparativereligion.com/hinduism/vedas/yajur_veda_kanda2.php Yamashita, Y. \& Yamashita, T. (2002). Report of the field research on the situation of female eachers in the five development regions of Nepal. Journal of Bunkyo Women's University, 2 (1), 9-32.

The author is an Assistant Professor at the Humanities and Management Unit, Kathmandu University, Dhulikhel. He can be reached at: eakprasad.duwadi@gmail.com 